\title{
Kúzlo zmyslov Davida Abrama
}

\section{Lubov Vladyková}

Envigogika 10 (3) - Recenze/Reviews

Publikováno/Published dne 26. 9. 2015

DOI: $\underline{10.14712 / 18023061.495}$

Recenzia: David Abram: Kouzlo smyslů: vnímaní a jazyk ve více než lidském světě (The Spell of the Sensuous: Perception and Language in a More-Than-Human World). Praha: DharmaGaia, 2013, 406 s. Z anglického originálu prekložili: M. Melechovská a J. Zemánek.

Review: The Spell of the Sensuous: Perception and Language in a More-Than-Human World. (1996) 
V práci Kouzlo smyslư: vnímání a jazyk ve více než lidském světě (2013) ${ }^{1}$ David Abram² čerpá z rôznych zdrojov: z filozofie M. Merleau-Pontyho, fenomenológie E. Husserla, balijského šamanizmu, Apache rozprávania a z vlastných skúseností a zručnosti kúzelníka. $\mathrm{Na}$ tejto báze sa pokúsil odhalit' jemnú závislost' ludskej existencie, l'udského poznania na životnom prostredí. Štruktúra textu je precízne dizajnovaná a pozostáva zo siedmich kapitol. Súčastó textu sú poznámky, dodatok J. Zemáneka Jak ladit s řečí země a bibliografia D. Abrama.

D. Abram už v úvode práce v kapitole nazvanej Ekológia kúzla dáva do protikladu spôsob, akým staré ,primitívne' kultúry pristupujú k prírodnému svetu, s analogickým prístupom $v$ západnej ,technickej a mechanickej kultúre'. Chce tým poukázat́ na to, že environmentálne problémy vznikajú z nedostatku bezprostredného kontaktu medzi ludskou spoločnostou a mimoludskou prírodou. Túto situáciu chce riešit́ tak, že podporuje viac na zmysly orientované používanie jazyka a radikálne výraznejšie využívanie zmyslov, aby sa mimoludský svet chápal ako živá vec. Ako živý a oduševnený pozemský kozmos - ako spoločenstvo subjektov a inegmatických, výrazových síl, ktorých inteligencia nás môže informovat' i učit'.

Pre D. Abrama je modernizácia zlá už vo svojich koreňoch, pričom tieto korene nevidí $v$ industrializácii ani privatizácii majetku, ale $v$ jazyku, ako sa vyvinul do písaných foriem, abstrahovaných od prírodného sveta. Podl'a Abrama „Prevládajúce ponímanie jazyka, prinajmenšom od vedeckej revolúcie... pokladá akýkol'vek jazyk za súbor lubovol'ných, avšak konvenčne dohodnutých slov či ,znakov' spojených isto formálnym systémom syntaktických a gramatických pravidiel. Jazyk je z tohto pohladu len akýmsi kódom, druhom reprezentácie skutočných vecí a udalostí vnímaného sveta, s ktorým nemá žiadne vnútorné, nearbitrárne spojenie..." (101). Uvádza, že existujú kultúry, kde jazykový prejav je spätý špecifickým spôsobom s , hovoriacou zemou', kultúry, kde „....stále prevažujú tradičné orálne, domorodé spôsoby skúsenosti - kultúry, ktoré svoju zmyslovú participáciu nikdy celkom nepreniesli do písaného slova" (s. 171).

V podstate - devastácia environmentu a ekologická kríza začali devastáciou šírky jazyka, jeho abstrahovaním od priamej referencie na prírodu v určitom čase a na určitom mieste. Tým určitým miestom je grécka spoločnost', kde nastal kritický obrat vo vztáahoch ludí ku svetu. V štvrtej kapitole - nazvanej Animizmus a alfabeta D. Abram pripisuje tento kritický obrat - klasickej gréčtine, prvému súboru symbolov používaných na medziludskú komunikáciu bez bezprostredného odkazu na prírodný svet. Čínske písmená a hebrejske aleph-beth boli odvodené priamo z vecí, javov v prostredí, ktoré sa znaky snažili reprezentovat'. Napríklad za inšpiráciu pre čínske znaky sa považuje pozorovanie stôp vtákov na zemi. Aj prvé hebrejské písmeno, aleph - čo je starohebrejské slovo znamenajúce vôl má tvar, ktorý pripomína hlavu vola s rohami. Aj ked' grécka abeceda vzišla z relatívne priamej transformácie hebrejského aleph-beth, Gréci nikdy nemali priame odkazy na prostredie.

Mnohí teoretici a filozofi považovali grécku spoločnost' za obrat vo vzt́ahoch l'udí ku svetu. Väčšina z nich však založila toto rozdelenie na hierarchii poznania dosiahnutého gréckymi filozofmi a nie na niečom, čo je inherentné gréckemu jazyku. Gréci ako prví

\footnotetext{
${ }^{1}$ Práca (jej rozsah: 407 strán) pozostáva zo siedmich kapitol, súčastou práce sú poznámky, doslov editora a register.

${ }^{2}$ David Abram (1957) je americký filozof, kultúrny ekológ a umelec. Vo svojej tvorbe sa venuje premosteniu filozofických tradícií, environmentu a kultúrnej, resp. sociálnej ekológie.
} 
filozoficky rozliśili medzi poznaním (myslenie a chápanie) a konaním. Napríklad Aristoteleles chápal racionálne poznanie ako najvyššiu, sebestačnú a uzavretú formu aktivity, ktorá vzniká sama zo seba a sama sa riadi. Bolo ideálne a večné, nezávislé na zmene a teda nezávislé na svete, v ktorom lúdia konajú a žijú, svete, ktorý prežívame percepčne a prakticky. ,Čistá aktivita' sa jednoznačne oddel'ovala od praktického konania. $V$ tejto súvislosti D. Abram uvádza „Až so vznikom fonetickej abecedy a jej osvojením starovekými Grékmi stratili písané symboly všetky zrejmé väzby k širšiemu svetu vyjadrujúcich sa bytostí. Každý takýto znak začal odkazovat' len k ludskej sfére: každé písmeno bolo spojované výlučne s gestom či zvukom ludských úst. Tieto symboly už nemohli fungovat' ako okná otvorené do viac než ludského priestoru síl, ale len ako zrkadlá, ktoré l'udskú formu odrážajú spät́ na ňu samú" (s. 170).

Vynález písma podla Abrama vytvoril podmienky, z ktorých potom vyplynul každý následný krok modernizácie. Mechanizmy odcudzenia od viac než ludského priestoru síl boli dvojaké. V prvom rade - písaný jazyk priniesol percepčné odcudzenie, ktorým zmysly strácajú spojenie a participáciu medzi ,'́udskými zmyslami a zemským terénom'. Druhým odcudzením je jazykové odcudzenie, ktorým jazyk, príbehy, dejiny strácajú spojenie s ,príbehmi našich predkov's duchom konkrétnych miest. D. Abram tvrdí, že písmo umožnilo po prvýkrát oddelenie od priamo prežívaného sveta. Podl'a neho sa nástup písma časovo zhoduje s rastom lúudskej schopnosti ,manipulovat' a kultivovat' zem'. Zaznamenaný jazyk je teda priamo zodpovedný za pol'nohospodársku revolúciu. Tak sa vyvinuli nekočovné, koncentrované l'udské usadlosti s delbou práce a následne došlo k odcudzeniu ich vztahu s mimoludským svetom.

Terminologické penzum autora je rozhodujúco ovplyvnené predstavou sveta ako more-than-human world (ktorý obsahuje viac než iba človeka). Ako alegóriu na výrazné časové a priestorové oddelenie západného sveta a sveta, ktorý obsahuje viac než iba človeka, Abram rozpráva príbeh (vypožičaný od G. Snydera) o austrálskom domorodcovi, ktorý je vyvedený z rovnováhy jazdou na nákladiaku po krajine. Podla tradície musí počas cestovania rozprávat́ príbehy o krajine - čo je spôsob sprievodcu po krajine, mnemotechnický prostriedok a spôsob zabavenia mysle - ale podla tradície sa cestuje pešo. Poučenie, ktoré z toho vyplýva, je, že ak l'udia nemajú kontakt so zemou, zabúdajú na ,dobrý život. Ak sa naruší bezprostredný kontakt so zemou - jako v prípade šoférovania namiesto chôdze - l'udia nedokážu konat' správne. Abramovo posolstvo je teda také, že život nefunguje $v$ rozsahu technického sveta, $v$ jeho čase a priestore. Ĺud'om je potrebné neustále pripomínat' zmyslové a jazykové spojenie so svetom, ktorý obsahuje viac než iba človeka. D. Abram poznamenáva, že staré ,primitívne' kultúry sa vyhýbajú karteziánskej idei dualizmu subjekt/objekt, podla ktorej jednotlivci sú úplne oddelení od centrá schopného konat' a komunikovat' vo, vonkajšom' svete iba tak, že sa úplne riadia vnútorným procesom myslenia. Ĺudia, ktorí žijú obkolesení svetom, ktorý obsahuje viac než iba človeka, sa podl'a Abrama nedopúśt́ajú modernej chyby považovat' sa za oddelených od prírodného sveta a všetkého diania $v$ ňom, resp. za divákov $v$ tomto svete. M. Merleau-Ponty chápal vzt́ah medzi skúsenost́ou a poznaním ako spôsob, ktorým si ludia požičiavajú štruktúru zo sveta, $\checkmark$ ktorom participujú - pre budovanie svojho myslenia. $\vee$ tomto kontexte $D$. Abram $v$ zásade tvrdí, že moderná civilizácia sama seba klame, ked' sa domnieva, že naše písomné dokumenty nám poskytujú mocné nazeranie do galaxií a všade tam, kde môžeme sústredit́ našu pozornost́. Abram je toho názoru, že naše zmysly postačujú na meranie pravdy. Ale aby toto tvrdenie obhájil, musí redefinovat́ pravdu. Musí sa skončit' s nazeraním na pravdu ako na statický fakt a je nutné začat ju vnímat' ako vyvíjajúci sa vztáah. Pravdu preto treba hodnotit' podl'a kvality vzt́ahu, čo Abram nazýva posudzovanie toho, či niečo ,dáva zmysel', teda v pravom slova zmysle, oživuje zmysly'. V ekologickom význame teda k pravde pristupujeme nie zhromažd'ovaním faktov či konštatovaním, ale skvalitňovaním našich skúsenostných vztáahov s okolitým spoločenstvom, ktoré obsahuje viac než iba človeka. Na 
druhej strane, pravda sa nemôže spájat' so žiadnym faktom alebo konštatovaním vysloveným lud'mi, ktorí pôsobia deštruktívne voči svojmu prostrediu, pretože len: „'udské spoločenstvo, ktoré žije vo vzájomne prospešnom vzt́ahu s okolitou zemou je spoločenstvom, o ktorom môžeme povedat', že žije v pravde.... Civilizácia, ktorá trvale pustoší živú zem, ktorú obýva, nie je s pravdou dobre oboznámená" (s. 319). Podla Abrama, naša civilizácia žije nesprávne, pretože naše vztáahy s ,okolitou zemou' sú úzke a plytké a to zas je dané našim jazykom. Môžeme zlepšit' našu spôsobilost' ,dávat' zmysel' a rozvíjat' výhodné vztahy so svetom okolo nás tak, že sa budeme vyhýbat' spôsobom hovorenia, ktoré nás separujú a odsúvajú od sveta, ktorý obsahuje viac než iba človeka. Prísne vzaté: budeme používat' jazyk, ktorý sústred'uje našu spriaznenost' so svetom (ktorý obsahuje viac než iba človeka), do modelov nášho myslenia a konania.

Neznamená to, že Abram explicitne podporuje návrat do čias kočovania. Avšak v Abramovej nekritickej pokore k starému spôsobu života je skrytá viera, že nasledovanie tohto spôsobu života predstavuje prinajmenšom jednu z možností a rozhodne lepšiu možnost' než je tá, ktorú dnes žijeme. Podl'a Abrama pôvodné kultúry nám dnes poskytujú určitú poistku proti strachu a neistote pri odklone od modernej technokratickej kultúry.

Vari najdôležitejším obmedzením Abramovho kréda je to, že sa odvoláva na hlasy niekolkých málo ludí, ktorí vedia o spojení s prírodou, ak to ponechajú v rovine osobnej skúsenosti. Sú iba niekolkými hlasmi v porovnaní s množstvom iných hlasov s rovnako platnou skúsenostou, na základe ktorej oddelujú svoje životy od prírody. Podla Abramových kritérií pravdivosti a omylu, ludia - ktorým chýba jazyk alebo zmyslová skúsenost́ s prírodou - sa jednoducho mýlia. Aj ak sa ukáže, že väčšina l'udí, ktorých by Abram klasifikoval ako mýliacich sa, zastáva environmentálne nekompatibilnú etiku, predpokladajúc, že sa mýlia od začiatku, nedáva sa im šanca dokázat́ opak, kedže nesúhlasia s prechodom na nový jazyk podl'a Abramovho výberu, ani na nové miesto vo svete, ktorému nemusia rozumiet́.

Namiesto Abramom konštruovaného ,nového tela jazyka', jediného jazyka alebo slovníka harmonizujúceho so zemou, dnešná koncepcia toho, čo je potrebné pre zabezpečenie väčšej environmentálnej zodpovednosti, spočíva v aktívnejšej a komplexnejšej diskusii o otázkach ludských vzt́ahov so svetom a medzi sebou a o tom, čo sa má stat' $s$ nami a s tým, čo sme vytvorili. Rozhodujúci projekt spočíva teda $v$ úsilí poskytnút všetkým l'ud'om predbežné podmienky pre slobodnú komunikáciu - napríklad vytvárat́ vhodnú komunikačnú bázu pre koncepty a modely reflexívnej praxe $v$ aplikovanej etike a ekologickej výchove - a nie nútit' ludí akceptovat' jazyk a/alebo životný štýl, ktorý nepovažujú za niečo lepšie - podla určitých univerzálnych kritérií dobra. Strata perspektívy neustálej komunikácie je dokonca desivejšia než strata starovekých pokladov sveta, pretože dochádza $k$ strate možnosti konštruovat' hodnotové úsudky a tak ovplyvňovat' naše budúce konanie a zvyky.

Bolo by možné tvrdit', že väčšinu problémov spojených s Abramovou argumentáciou, možno odložit bokom, v záujme väčšieho dobra jeho kritickej reflexie. Abramovo jednostranné pohŕdanie modernitou a nekritické uprednostňovanie ,nástrojovej' techniky a kočových kultúr je problematické, avšak takéto radikálne obraty $v$ dominantných hodnotových súdoch môžu byt' stimulujúce a môžu podporit' kreativitu v systéme, ktorý potrebuje reformovat'. Ved' nemožno nesúhlasit' s konštatovaním, že „[s]kutočný ekologický prístup sa nesnaží dospiet' k mentálne predstavitel'nej budúcnosti, ale pokúša sa ešte hlbšie preniknút do zmyslovej prítomnosti. Snaží sa byt́ pozornejší voči ostatným životom, voči ostatným vnímajúcim a cítiacim formám...." (s. 329). Kedže jeho riešenie otázok vztáahu medzi človekom a prírodou je brilantné a výrečné, asi by bolo vhodné u Abrama tolerovat', že neberie do úvahy exponenciálny nárast faktorov, $v$ akých prebieha l'udský život dnes $\checkmark$ porovnaní s minulými časmi. Nie je táǎké pochopit', a často musíme súhlasit' s tým, že 
náklady na komfort civilizácie $v$ jej momentálnej štruktúre sú príliš vysoké. Ale môžeme vzniest́ voči Abramovmu argumentu námietku z dôvodu jeho ,presvedčenia'. S väčšinou klasických pragmatistov má spoločné vedecké základy, ktoré predchádzali jeho záujmu o filozofiu. Prečo potom uprostred svojho výkladu o mágii a mysticizme neprejavuje Abram ani kúsok pokory pred ,mágiou' vedeckej metódy? Je zvláštne, že vedec - bez ohladu na jeho zameranie - má tak málo čo povedat' o prínose vedy.

Doc. PhDr. Lubov Vladyková, PhD., Katedra aplikovanej etiky, FF UPJŠ, Moyzesova 1, budova Aristoteles, 04001 Košice, Mail: lubov.vladykova@upjs.sk 